\title{
A U-Pb Study of Zircons from a Lower Crustal Granulite Xenolith of the Spanish Central System: A Record of Iberian Lithospherie Evolution from the Neoproterozoic to the Triassic
}

\author{
Javier Fernández-Suárez, ${ }^{1}$ Ricardo Arenas, Teresa E. Ieffries, ${ }^{2}$ \\ Martin I. Whitehouse, and Carlos Villaseca \\ Departamento de Petrología y Geoquímica, Universidad Complutense, 28040 Madrid, Spain \\ (e-mail: ifsuarez@geo.ucm.es)
}

\begin{abstract}
A B ST R A CT
A U-Pb laser ablation inductively coupled plasma mass spectrometry and secondary ion mass spectrometry geochronological study has been performed on zircons from a felsic granulite xenolith from the lower crust under the Variscan belt of Iberia. The ages obtained reveal zircon-forming events that span from the late Neoproterozoic (Cadomian-Avalonian orogeny) to the early stages of the opening of the Atlantic Ocean in the Mesozoic, through Cambro-Ordovician rifting, Devono-Carboniferous Variscan-Alleghenian collision, and Permian-Triassic extension and uplift. The U-Pb age groups found in zircons from this single lower crustal xenolith (ca. 220, 250, 280-310, 460490,525 , and 550-590 Ma) record at least one complete cycle of closing and opening of oceanic basins and collision of continental masses. Zircons from the felsic granulite xenolith contain a synthesis of the geochronological information found on the surface geology and record most but not all malor lithospheric events in the region in a ca. 400m.yr. period.
\end{abstract}

Online enhancement: table.

\section{Introduction}

Insight into the nature of the lower continental crust and the chronology of major events occurring in the lower crust-upper mantle region is essential. to further our understanding of lithospheric evolution and crustal growth processes (Rudnick 1995). Apart from the indirect evidence provided by various geophysical methods, information on lower crustal rocks comes from the study of either tectonically exhumed lithospheric fragnents (e.g., the Ivrea zone of northern Italy; Pin and Vielzeuf 1983) or xenoliths entrained mainly in basaltic and alkaline magmas (Downes 1993).

The study of lower crustal xenoliths is a powerful. tool that has provided many constraints and a wealth of information on the nature and evolution of the lower continental crust. However, most studies of lower crustal xenoliths have focused on their mineralogy, geothermobarometry, major- and trace-element geochemistry, stable and radiogenic isotope signatures, and petrophysics. Fewer studies have been devoted to decoding the crucial geochronological information contained in these xenoliths. Given the difficulty of obtaining reliable $\mathrm{Rb}-\mathrm{Sr}$ or Sn-Nd whole-rock or mineral isochron ages (Rudnick and Williams 1987; Rudnick and Cameron 1991; Chen et al. 1994), zircon U-Pb dating has emerged as the most robust method to obtain reliable age information from lower crustal xenoliths. The U-Pb chronometer of zircon is a unique calendar of major events of creation, destruction, and recycling in the Earth's lithosphere because zircon retains a record of its crystallization history as a result of the slow diffusion kinetics of $\mathrm{U}, \mathrm{Th}$, and $\mathrm{Pb}$ and its resilience to high-grade metamorphic reactions, even those surpassing anatectic conditions (Watson 1996). The term "resilience" is 
used in the sense of being able to survive as a solid phase and retain all or part of the isotopic information encoded before a given geological episode. Zircon (a single grain or a suite of grains in a given host rock) is also capable of recording events postdating its original crystallization; these events may span hundreds or even thousands of millions of years. Therefore, zircons from lower crustal xenoliths may record all or most geological events that have occurred in the lower crustal region from which they were eventually extracted. These events may be manifest or not in the middle or upper crust, or, conversely, the lower crust may or may not record events that are manifest in the middle and upper crust (e.g., Downes et al. 2002). Time lines connecting events in the lower crust and the middle-upper crust may provide important constraints in elucidating the lithospheric evolution of cratonic areas, rifting environments, active margins, and collisional belts (e.g., Chen et al. 1994).

So far, the most useful U-Pb geochronological information from lower crustal xenoliths has been provided by spatially resolved microanalytical techniques, namely, ion microprobes (e.g., Höltä et al. 2000; Downes et al. 2002). Methodological advances in isotope dilution-thermal ionization mass spectrometry (ID-TIMS) U-Pb geochronology have also allowed precise and spatially resolved U-Pb information to be obtained from zircons in lower crustal xenoliths (Moser and Heaman 1997; Schmitz and Bowring 2000; Davis et al. 2003). Recent developments in the technique of laser ablation inductively coupled plasma mass spectrometry (LA-ICP-MS) U-Pb dating (Jeffries et al. 2003; Jackson et al. 2004; Zheng et al. 2004) have also allowed spatially resolved zircon U-Pb data to be obtained.

In this study, we report $\mathrm{U}-\mathrm{Pb}$ zircon ages from a lower crustal felsic granulite xenolith entrained in a Permo-Triassic ultrabasic alkaline dike swarm of the Spanish Central System (Villaseca et al. 1999 and references therein). U-Pb data have been obtained by LA-ICP-MS and are among the few examples of spatially resolved U-Pb dating of granulite zircons using this technique (e.g., Zheng et al. 2004). An additional subset of U-Pb analyses was obtained by secondary ion mass spectrometry (SIMS; NORDSIM's CAMECA IMS 1270 ion microprobe) to test the reproducibility of $\mathrm{U}-\mathrm{Pb}$ data by these two techniques. We emphasize that the SIMS study was not aimed at a comparison of the two techniques, which is beyond the scope of this work, but was simply intended to ensure that firstorder conclusions would not be affected by the use of one technique or the other.

\section{Geological Background}

The Spanish Central System (SCS) is located within the Central Iberian Zone of the Variscan belt of Iberia (fig. 1), which is part of the hinterland of the western European Variscan Belt (WEVB) resulting from the Laurussia-Gondwana collision in Carboniferous times (Martínez-Catalán et al. 1997). The SCS is a large granitoid-gneiss complex with $\geq 10,000 \mathrm{~km}^{2}$ of outcrop surface. The granitoids intruded as several magmatic pulses between ca. 325 and $280 \mathrm{Ma}$ (Villaseca et al. 1995) into a continental crust mainly composed of Precambrian-Lower Cambrian metasedimentary rocks and orthogneisses derived from Cambro-Ordovician granitoids (Valverde-Vaquero and Dunning 2000). An alkaline ultrabasic dike swarm intruded into the SCS in end-Permian times (Villaseca et al. 2004). These dikes consist mainly of ultramafic camptonitic lamprophyres and contain a suite of lower crustal granulite xenoliths (Villaseca et al. 1999). Emplacement of this dike swarm took place during a phase of anorogenic alkaline magmatism related to the initial stages of North Atlantic rifting (Villaseca et al. 1991). The lower age limit of the alkaline dike swarm is constrained by the cross-cutting Messejana-Plasencia dike, emplaced at ca. $200 \mathrm{Ma}$ (Sebai et al. 1991), which is one of the largest dolerite dikes belonging to the Mesozoic Central Atlantic Magmatic Province (Cebriá et al. 2003). An upper age limit is provided by the youngest Variscan granitoids, emplaced in the area at ca. $280 \mathrm{Ma}$ (Villaseca et al. 1995 and references therein). In this study, zircons from one alkaline dike have been

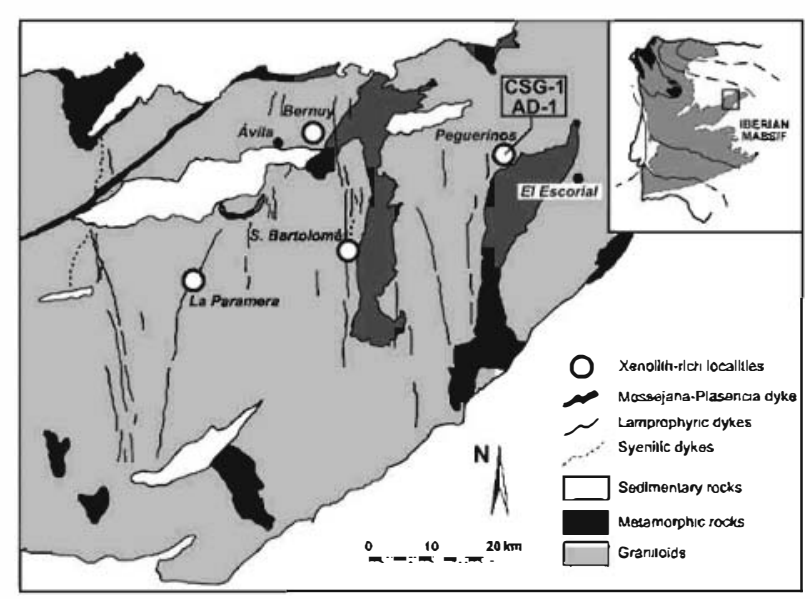

Figure 1. Simplified geological sketch showing the Spanish Central System and the location of samples CSG-1 and AD-1. 
dated by LA-ICP-MS in order to obtain further constraints on the emplacement age of these dikes.

The main types of lower crustal granulite xenoliths found in these alkaline dikes, their petrological features, mineralogy, geothermobarometry, major- and trace-element geochemistry, and $\mathrm{Sr}-\mathrm{Nd}$ isotope signatures have been reported elsewhere (Villaseca et al. 1999). The xenolith sample collected for this study (sample CSG-1) is a felsic metaigneous granulite, the most abundant type ica. $95 \%$ ) of xenolith found in the dike swarm. The sample was collected near the town of Peguerinos, $50 \mathrm{~km} \mathrm{NW}$ of Madrid (fig. 1). The studied sample corresponds to the "felsic peraluminous type" of Villaseca et al. (1999) and is composed of garnet $+\mathrm{K}$-feldspar + plagioclase + quartz \pm phlogopite \pm orthopyroxene. Texturally, it is a massive granoblastic type with weak mineral orientation. Thermobaromatric calculations based on mineral paragenesis (Villaseca et al. 1999) indicate equilibration conditions of ca. $850^{\circ}-950^{\circ} \mathrm{C}$ and $7-11 \mathrm{kbar}$. This xenolith type is characterized by $\varepsilon_{\mathrm{Nd}}$ values jat $300 \mathrm{Ma}$ ) ranging from -1.4 to -8.2 and ${ }^{*} \mathrm{Sr} /{ }^{* i} \mathrm{Sr}$ ratios (at $300 \mathrm{Ma}$ ) between 0.7059 and 0.7130 .

\section{$\mathrm{U}-\mathrm{Pb}$ Geochronology}

Zircon Features. Zircons from the dike Isample AD-1) are mainly short, stubby prisms with a pinkish hue and contain abundant cracks and inclusions. Granulite xenolith CSC-1 contained two main morphological zircon types. About $75 \%-80 \%$ of the zircons were equant, multifaceted, stubby crystals (henceforth referred to as "type A"! ranging in size between ca. 85 and $250 \mu \mathrm{m}$. Decompression partings (Rudnick and Williams 1987! are observed in some grains. The second morphological type (henceforth named "type B") consists of long to stubby or tabular subhedral prisms with poorly developed pyramidal taces and a size range similar to that of type A crystals.

Internal features of both types of zircon were studied by cathodoluminescence (CL) in 100 grains before U-Pb analysis. The most characteristic internal features are shown in figure 2. Most type B zircons contain cores and overgrowths with oscillatory zoning (fig. 2.1-2.5), whereas $\$ 15 \%$ of the type A crystals contain cores (fig. 2.12, 2.13). Type A zircons display concentric oscillatory, sector, or fir tree zoning (e.g., fig. 2.14, 2.11, and 2.10, respectively|. Some type A grains feature thin, bright, luminescent rims (fig. 2.9), and in a few of them,
CL imaging revealed very small $(<20 \mu \mathrm{m})$ cores (fig. $2.6,2.12,2.15)$.

LA-ICP-MS. Zircons were separated at the Complutense University of Madrid and subsequently handpicked and mounted for analyses following the procedures described by Jcftrics et al. (2003). LAICP-MS analyses were performed at the Natural History Museum (London). Analytical instrumentation consisted of a UP213 frequency-quintupled Nd:YAG-based laser ablation system (NewWave Research, Fremont, CA) coupled to a PQ3 quadrupole-based ICP-MS instrument (Thermo Elemental) with an enhanced-sensitivity (S-Option) interface. A mixture of helium and argon was used to flush the ablated sample as reported by Jeffries et al. (2003). Instrument and operating parameters used for individual zircon analyses are also as given by Jeffries et al. (2003). Analytical protocol, data treatment, analysis of time-resolved isotope ratio signals, age and error calculation, assessment of data quality, and data rejection criteria are those outlined by Fernández-Suárez et al. (2002), Jeffries et al. (2003), and Murphy et al. (2004). The main difterence in analytical procedure with respect to that reported in the above studies is the use of a nominal beam diameter of $18 \mu \mathrm{m}$ in order to achieve the spatial resolution needed for complex granulite zircons. Rastering (scanning) along lines $30-45 \mu \mathrm{m}$ long (to minimize lascr penetration in the third dimension) resulted in ablation pits ca. 15-20 $\mu \mathrm{m} \times 35-50 \mu \mathrm{m}$ (fig. 2.19-2.21) with depth variable upon collection time. Zircon 91,500 (Wiedenbeck et al. 1995) was used as an external standard. Measurements of this zircon as an unknown during the analytical sessions yielded weighted averages $( \pm 2 \sigma)$ tor the ${ }^{206} \mathrm{~Pb} /{ }^{238} \mathrm{U}$ and ${ }^{207} \mathrm{~Pb} /{ }^{206} \mathrm{~Pb}$ ages of $1062.9 \pm 3 \mathrm{Ma}\left(n=12\right.$; certified ID-TIMS ${ }^{206} \mathrm{~Pb} /$ ${ }_{22 \mathrm{c}} \mathrm{U}$ age $=1062.4 \pm 0.4 \mathrm{Ma}$ ) and $1064.7 \pm 3.5 \mathrm{Ma}$, respectively $\left[n=12\right.$; certified ID-TIMS ${ }^{207} \mathrm{~Pb} /{ }^{206} \mathrm{~Pb}$ age $=1065.4 \pm 0.3 \mathrm{Ma}$ ).

SIMS. SIMS U-Pb analyses on a subset of 20 zircons from the same mount were performed at the NORDSIM laboratory, Natural History Museum (Stockholm), with a CAMECA IMS 1270 ion microprobe. The spot diameter was ca. $30 \mu \mathrm{m}$, and data were calibrated against zircon standard 91,500 (Wiedenbeck et al. 1995). A detailed description of the analytical procedure, protocol, and age calculation is given by Whitehouse et al. (1999). LA-ICPMS and SIMS U-Pb analyses were performed on the same CL domains of the zircons (fig. 2.19-2.21) in order to ensure that first-order conclusions based on $\mathrm{U}-\mathrm{Pb}$ results are not biased or altered by the use of one technique or the other. As stated above, it is beyond the scope of this work to report any de- 


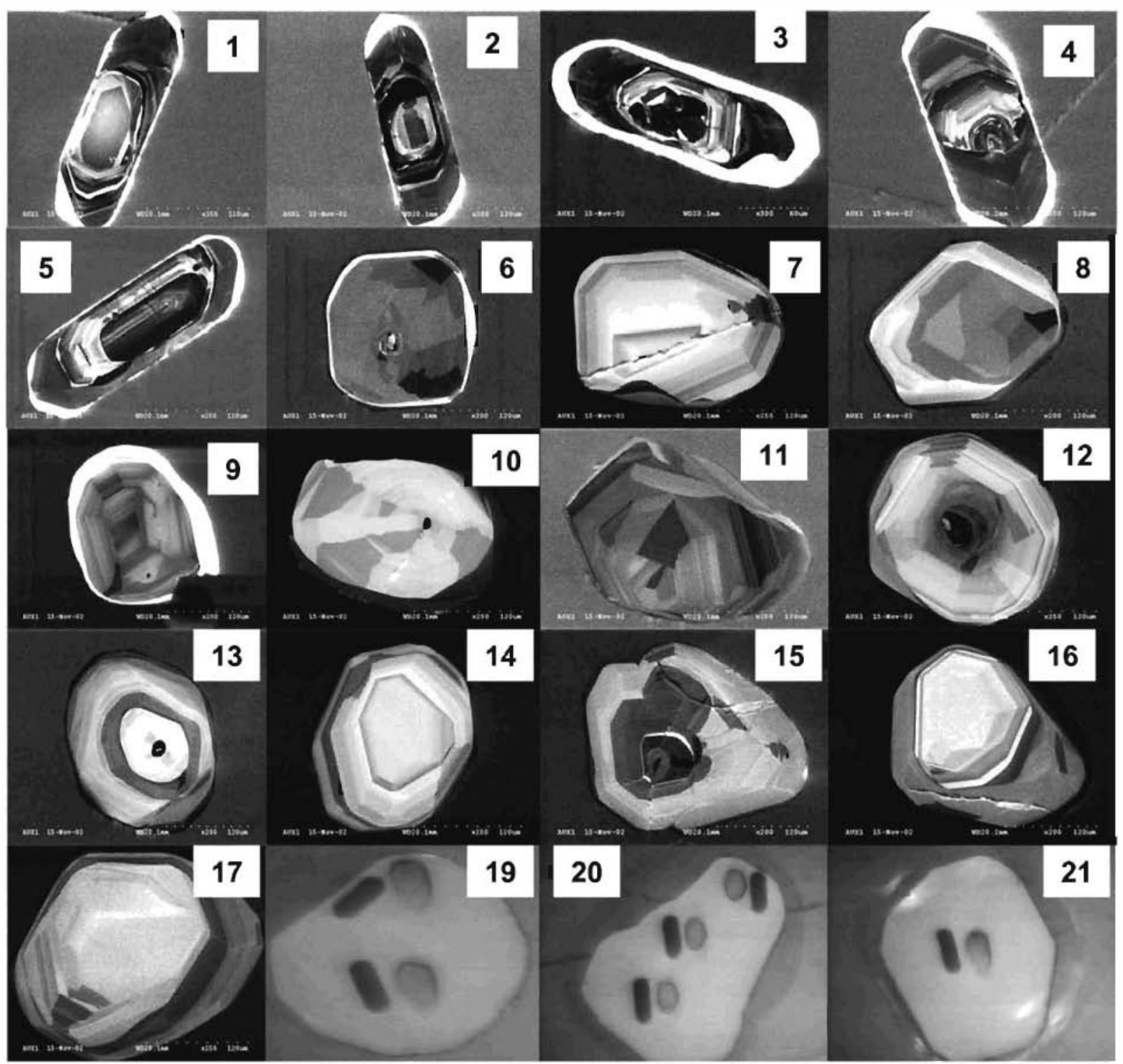

Figure 2. 1-17, Cathodoluminescence images showing the main internal features of zircons from granulite xenolith CSG-1 (see text for details). 19-21, Reflected-light images of zircons illustrating two-dimensional spatial resolution achieved with LA-ICP-MS analyses (elongated dark pits) compared to typical SIMS images (elliptical gray pits).

tailed comparison of the performance and results of the two techniques.

Results. The results of LA-ICP-MS and SIMS U$\mathrm{Pb}$ analyses are reported in tables $\mathrm{Al}$ and 1 , respectively. (Table Al is available in the online edition or from the Journal of Geology office.) The ages labeled "reported age" in table A1 are calculated as follows. For concordant analyses (ages whose corresponding isotope ratios have a $2 \sigma$ error ellipse that, to a greater or lesser extent, overlaps the concordia curve), we report concordia ages (Ludwig
1998 and $2 \sigma$ errors. For normally discordant analyses (plotting below concordia), we report the ${ }^{207} \mathrm{~Pb} /$ ${ }^{206} \mathrm{~Pb}$ age and $2 \sigma$ error. It should be noted that LAICP-MS U-Pb analysis of small zircon domains requires a small beam diameter, short line rasters (preferred over stationary spot analysis because it reduces elemental fractionation; Jeffries et al. 2003 ), and short collection times (often $<30 \mathrm{~s}$ ), and as a consequence, the precision of ${ }^{207} \mathrm{~Pb} /{ }^{206} \mathrm{~Pb}$ ratios is low because of the combined effect of poor counting statistics and the small volume of sample an- 
Table 1. SIMS U-Th-Pb Results

\begin{tabular}{|c|c|c|c|c|c|c|c|c|c|c|c|c|c|}
\hline \multirow[b]{3}{*}{$\begin{array}{l}\text { Sample } \\
\text { CSG-1 spot }\end{array}$} & \multirow[b]{3}{*}{$\mathrm{Th} / \mathrm{U}$} & \multicolumn{8}{|c|}{ Isotopic ratios and $1 \sigma$ errors } & \multirow{3}{*}{$\begin{array}{c}208- \\
\text { corrected } \\
\text { age 'talal }\end{array}$} & \multirow{3}{*}{$\begin{array}{c}207- \\
\text { corrected } \\
\text { age } \pm 2 \sigma \\
\{\mathrm{Ma} \mid\end{array}$} & \multirow{2}{*}{\multicolumn{2}{|c|}{ LA-ICP-MS ages }} \\
\hline & & \multicolumn{2}{|c|}{${ }^{2 c 7} \mathrm{Ph} i^{2 * \mathrm{CP}} \mathrm{Ph}$} & \multicolumn{2}{|c|}{${ }^{207} \mathrm{~Pb}^{15} \mathrm{U}$} & \multicolumn{2}{|c|}{${ }^{23 s} \mathrm{~Pb}_{i}{ }^{\prime 23} \mathrm{U}$} & \multicolumn{2}{|c|}{${ }^{200} \mathrm{~Pb} ;{ }^{2} \mathrm{Th}$} & & & & \\
\hline & & Ratio & $\begin{array}{c}\text { Error } \\
|\%|\end{array}$ & Ratio & $\begin{array}{c}\text { Error } \\
1 \% !\end{array}$ & Ratio & $\begin{array}{c}\text { Error } \\
|\%|\end{array}$ & Ratio & $\begin{array}{c}\text { Error } \\
\% \%\end{array}$ & & & $\begin{array}{c}\text { Concordia } \\
\text { age } \pm 2 \sigma|\mathrm{Ma}|\end{array}$ & Analysis ${ }^{3}$ \\
\hline n1150-csg-15a & .33 & .0606 & 1.19 & .6991 & 1.96 & .0837 & 1.56 & .0284 & 5.89 & 516 & $516 \pm 16$ & $525 \pm 12$ & fel2al3 \\
\hline 150 -cse-15b & .37 & .0517 & 1.18 & .3404 & 2.05 & .0478 & 1.68 & .0152 & 5.95 & 301 & $301 \pm 10$ & $293 \pm 8$ & fel2al4 \\
\hline $150-\operatorname{csg}-27 a$ & .76 & .0527 & 1.97 & .3316 & 2.51 & .0456 & 1.56 & .0151 & 5.92 & 286 & $287 \pm 9$ & $283 \pm 7$ & $12 \mathrm{~b} 07$ \\
\hline n1150-csg-27b & .36 & .0555 & 2.24 & .3402 & 2.71 & .0445 & 1.52 & .0151 & 5.95 & 279 & $279 \pm 8$ & $283 \pm 8$ & fe12b08 \\
\hline n1150-csg-28a & .58 & .0548 & 1.49 & .3698 & 2.44 & .0490 & 1.92 & .0167 & 6.60 & 306 & $307 \pm 12$ & $312 \pm 8$ & fel2b09 \\
\hline 60-cse-30b & .57 & .0540 & 2.28 & .3397 & 2.75 & .0456 & 1.54 & .0144 & 6.01 & 287 & $287 \pm 9$ & $287 \pm 10$ & fel2b11 \\
\hline $0-\operatorname{csg}-30 c$ & .09 & .0512 & 1.53 & .3233 & 2.15 & .0458 & 1.51 & .0128 & 9.72 & 289 & $289 \pm 9$ & $284 \pm 5$ & $\mathrm{fe} 12 \mathrm{~b} 12$ \\
\hline $150-\operatorname{csg}-34 a$ & .76 & .0525 & 1.07 & .3424 & 1.86 & .0473 & 1.52 & .0144 & 5.79 & 299 & $298 \pm 9$ & $306 \pm 7$ & fel2bla \\
\hline n1150-csg-34b & .72 & .0522 & 1.18 & .3342 & 1.94 & .0464 & 1.53 & .0139 & 5.82 & 294 & $292 \pm 9$ & $308 \pm 7$ & fel2bl4 \\
\hline n1150-csg-34c & 1.04 & .0496 & 3.94 & .3190 & 4.31 & .0467 & 1.76 & .0147 & 6.60 & 294 & $295 \pm 10$ & $292 \pm 5$ & fe12b15 \\
\hline $50-\operatorname{csg}-38 a$ & .73 & .0534 & 3.05 & .3327 & 3.50 & .0452 & 1.73 & .0152 & 6.18 & 282 & $284 \pm 10$ & $295 \pm 9$ & fel2b16 \\
\hline 1150 -cse. $a \delta b$ & .51 & .0585 & 2.68 & .3764 & 3.17 & .0467 & 1.70 & .0158 & 6.19 & 292 & $292 \pm 10$ & $285 \pm 8$ & $\mathrm{fe} 12 \mathrm{c} 05$ \\
\hline n1150-csg- $43 b$ & .61 & .0519 & 1.80 & .3231 & 2.38 & .0452 & 1.56 & .0147 & 5.96 & 284 & $285 \pm 9$ & $278 \pm 4$ & fel2c07 \\
\hline n1150-csg-50a & .49 & .0529 & 2.38 & .3445 & 2.86 & .0473 & 1.59 & .0160 & 6.14 & 296 & $297 \pm 9$ & $286 \pm 7$ & fe $12 \mathrm{cos}$ \\
\hline n1150-csg-57a & .42 & .0543 & 2.18 & .3489 & 2.73 & .0466 & 1.65 & .0156 & 6.08 & 292 & $293 \pm 10$ & $281 \pm 7$ & $\mathrm{fe} 12 \mathrm{c} 09$ \\
\hline n1150-csg $: 57 \mathrm{~h}$ & .11 & .0524 & 1.74 & .3173 & 2.33 & .0439 & 1.54 & .0148 & 6.17 & 277 & $277 \pm 8$ & $287 \pm 4$ & $\mathrm{fe} 12 \mathrm{c} 10$ \\
\hline n1150-csg-6a & .37 & .0556 & 3.51 & .3553 & 3.86 & .0464 & 1.61 & .0151 & 6.40 & 292 & $291 \pm 9$ & $297 \pm 5$ & $\mathrm{fe} 12 \mathrm{a} 05$ \\
\hline n1150-csg-7a & .44 & .0590 & 1.12 & .7563 & 1.99 & .0929 & 1.65 & .0278 & 5.84 & 574 & $573 \pm 18$ & $576 \pm 7$ & fel2a09 \\
\hline n1150-csp- $7 \mathrm{~b}$ & .66 & .0491 & 1.99 & .3124 & 2.51 & .0461 & 1.53 & .0133 & 6.17 & 293 & $292 \pm 9$ & $298 \pm 2$ & fel2a10 \\
\hline
\end{tabular}

Note. The $\mathrm{Pb} / \mathrm{U}$ errors include a propagated component representing the scatter and the standard data.

${ }^{a}$ See table A1.

alyzed (this obviously becomes particularly acute in low-uranium zircons).

The LA-ICP-MS analyses of CSG-1 sample zircons reported in table A 1 do not contain significant amounts of common lead (i.e., the corresponding age shift would be within analytical uncertainty). Rejection of analyses affected by significant amounts of common lead was based on the examination (and appropriate selection) of $\mathrm{U}-\mathrm{Pb}, \mathrm{Pb}-$ $\mathrm{Pb}$, and $\mathrm{Th}-\mathrm{Pb}$ time-integrated ratio signals, as detailed by Jeffries et al. (2003). In addition, U-Pb isotope data were run with the common $\mathrm{Pb}$ correction algorithm of Andersen $\{2002$ ! to ensure that none of the analyses finally considered (those reported in table A1) contain significant amounts of common lead (i.e., the common-lead content is insignificant with respect to the total uncertainty associated with the measurement of U-Pb and $\mathrm{Pb}-\mathrm{Pb}$ isotopic ratios). In the case of sample $\mathrm{AD}-1$, some analyses containing significant amounts of common lead were used to obtain a crystallization age based on the regression of uncorrected ratios through an assumed common-lead composition on a Tera-Wasserburg plot.

The ages reported in table 1 (SIMS data) are obtained as follows. The "207-corrected" age is obtained with the algorithm of Ludwig (2001), which is equivalent to the intercept (on a Tera-Wasserburg concordia plot) of a discordia forced through present-day common ${ }^{2: 77} \mathrm{pb} / \mathrm{pb}$ composition (Stacey and Kramers 1975). The "208-corrected" age is calculated with the algorithm of Ludwig (2001) us- ing the Th/U ratios reported in table 1 and assuming the common $-{ }^{208} \mathrm{~Pb} /{ }^{206} \mathrm{~Pb}$ composition of Stacey and Kramers (1975).

The main conclusion from duplicated LA-ICPMS and SIMS analyses on the same CL domains of the same zircon grains is that in all cases (19 analyses; table 1), the U-Pb LA-ICP-MS and SIMS ages are within analytical uncertainty of each other. Therefore, we are confident that LA-ICP-MS can be used to obtain reliable and moderately precise U$\mathrm{Pb}$ age information of zircons with protracted or multistage crystallization histories.

Ten LA-ICP-MS analyses (one analysis per grain) were periormed on zircons from the dike sample AD-1. Of these, five were rejected because of the effect of inclusions and fractures within the grains. The five remaining analyses are shown in figure 3 on a Tera-Wasserburg plot. A regression anchored at Stacey and Kramers's (1975) common-lead composition at ca. $250 \mathrm{Ma}$ yields an intercept age of $252 \pm 3 \mathrm{Ma}$, in agreement with the geological constraints reported above. This age is within the error bounds of the ID-TIMS and ion microprobe age of $247 \pm 5 \mathrm{Ma}$ reported by Gardien and Paquetue (2004) in zircons extracted from amphibolites collected at the ocean-crust transition of the western lberian margin. These authors suggest that this age may represent the emplacement/crystallization of gabbroic melts at the base of the Iberian Variscan crust in the early stages of rifting between the lberia and Newfoundland conjugate margins.

Data from granulite sample CSG-1 discussed in 


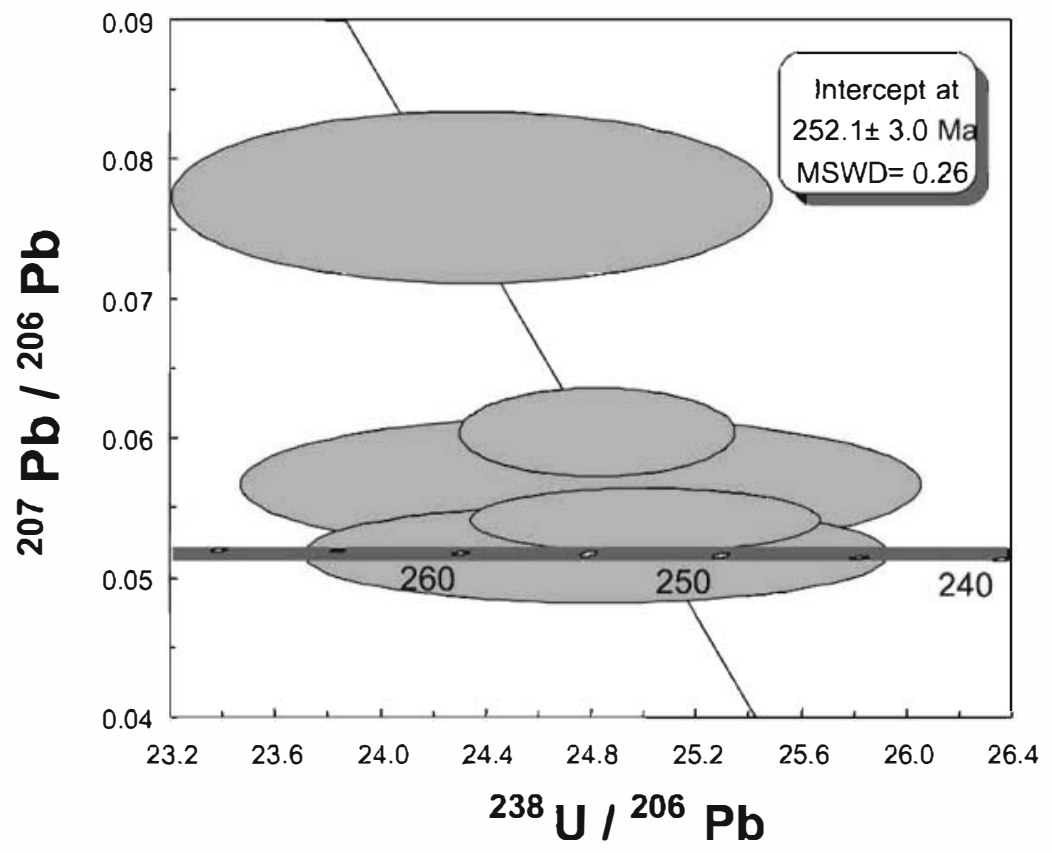

Figure 3. Tera-Wasserburg plot showing analyses of zircons from the dike sample AD-1. Ellipses represent $2 \sigma$ uncertainties (see text for details).

the following sections are presented in figures 4 and 5 , which show the existence of six age groups within the 69 reported LA-ICP-MS U-Pb analyses (table A1):

1. A group of 10 analyses on cores of prismatic zircons. These yielded late Neoproterozoic ages between ca. 550 and $588 \mathrm{Ma}$ (table A1). These analyses were performed on small cores and have low precision (e.g., compared to many analyses of the 277-312-Ma group, below), but they fall on an unconstrained discordia with an upper intercept age of $571 \pm 17 \mathrm{Ma}$ and a near-zero lower intercept (fig. $4 A$; all errors henceforth quoted at the $2 \sigma$ confidence levell. The two concordant analyses in this group have concordia ages of $551 \pm 11$ and $576 \pm$ $7 \mathrm{Ma}$ (table A1).

2. Two analyses of cores with overlapping error ellipses. These yielded a concordia age of $528.9 \pm$ 7.5 Ma (fig. 4B).

3. A group of six analyses (fig. $5 C$ ), five from cores in type $\mathrm{B}$ zircons and one from a core in a type $\mathrm{A}$ zircon (fig. 2.13). Of these six analyses, two are concordant, and their overlapping error ellipses yield a concordia age of $480.5 \pm 5.4 \mathrm{Ma}$ (fig. $4 D$ ). The remaining four analyses are discordant and, together with the two concordant analyses, fall on an unconstrained discordia line with a near-zero-age lower intercept $(-12 \pm 34 \mathrm{Ma})$ and an upper intercept at $477 \pm 19 \mathrm{Ma}$ (fig. $4 C$ ).
4. Forty-six concordant analyses (fig. 5A) with concordia ages ranging from $277 \pm 7$ to $312 \pm 8 \mathrm{Ma}$ (table $\mathrm{A} 1 ; 67 \%$ of the analyses). These analyses correspond to homogeneous (e.g., fig. 2.6), concentric, and sector-zoned CL domains in type A crystals and overgrowths in type B zircons (e.g., fig. 2.4). A relative age probability plot shows two maxima at 298 and $284 \mathrm{Ma}$ (fig. 5B). Within this age cluster, no apparent relationship exists between $\mathrm{U}-\mathrm{Pb}$ age and specific CL features in either type A or type B zircons.

5. Two analyses of rims in type B zircons with overlapping error ellipses. These yield a concordia age of $256 \pm 4 \mathrm{Ma}$ (fig. $5 \mathrm{C}$ ).

6. Two analyses of rims in two type A zircons (e.g., fig. 2.8) with overlapping error ellipses that yield a concordia age of $222.7 \pm 3.2 \mathrm{Ma}$ (fig. $5 \mathrm{D}$ ).

The two populations with discordant analyses (1 and 3) yield regressions with near-zero-age lower intercepts. Given that both discordant populations have concordant counterparts and that CL imaging and analysis of time-resolved signals ensure that no mixed-age domains were used for age calculation, we consider this to be the case for the discordant analyses in table $\mathrm{A} 1$ because of recent $\mathrm{Pb}$ loss, although we cannot discount that part of the discordance in these analyses is due to poor correction of U-Pb elemental fractionation (Jeffries et al. 2003). In the latter case, the ${ }^{207} \mathrm{~Pb} /{ }^{206} \mathrm{~Pb}$ ratios/ 

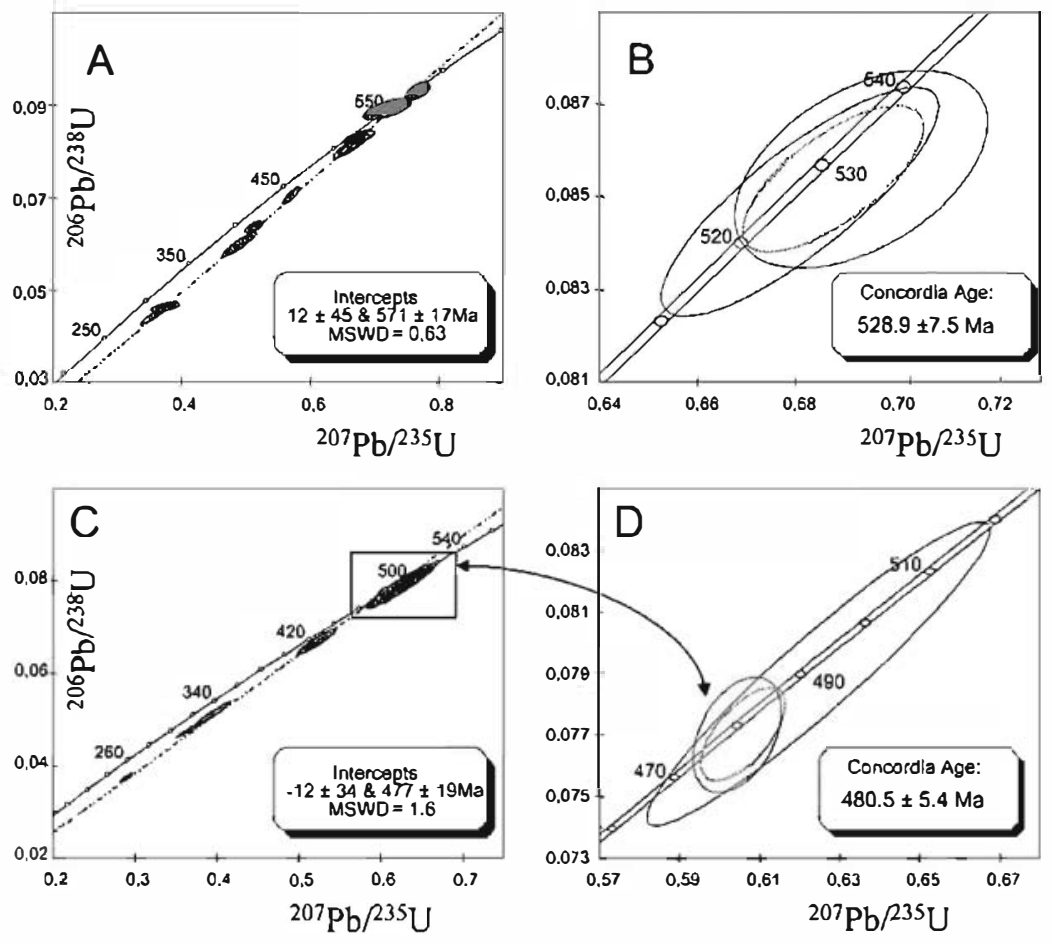

Figure 4. U-Pb concordia plots showing analyses of pre-Variscan zircons. Ellipses represent $2 \sigma$ uncertainties. Concordia (Ludwig 1998) and intercept ages are quoted at $2 \sigma$ confidence level.

ages would not be altered because the effect of $U$ $\mathrm{Pb}$ elemental fractionation is graphically equivalent to moving the data ellipses up or down a discordia line passing through the origin. Given that (1) the discordant analyses have concordant counterparts, (2) they fall on discordia lines whose unconstrained upper intercepts are within the error bounds of the concordant analyses and these ages correspond to geological events known from the surface geology, (3) CL-assisted ablation and inspection of isotope ratio time-integrated plots ensure that no mixed domains have been integrated for age calculation, and (4) the trends of these analyses on a Tera-Wasserburg plot show that they do not follow a common-lead contamination trend, we are confident that the ${ }^{207} \mathrm{~Pb} /{ }^{206} \mathrm{~Pb}$ ages for the reported discordant analyses are meaningful.

\section{Discussion}

Geological Significance of U-Pb Ages. Zircon U-Pb age data from the felsic granulite xenolith CSG-1 indicate that the Iberian lower crust records several events that produced zircon crystallization before the emplacement of the Permo-Triassic alkaline dike swarm that carried these xenoliths into the upper crust. The ages recorded by zircons in the lower crust match the age of events recorded in the surface geology of central Iberia, a feature found in other areas where U-Pb ages of lower crustal xenoliths are available (e.g., Rudnick and Williams 1987; Rudnick and Cameron 1991; Chen et al. 1994; Höltä et al. 2000; Downes et al. 2002).

The oldest age group, ca. 550-590 Ma, corresponds to late Neoproterozoic events related to the Cadomian-Avalonian-Pan-African orogeny (Fernández-Suárez et al. 2002). Ages in this time span have not yet been found in the orthogneisses of the SCS but correspond to the oldest igneous rocks exposed in neighboring areas of the Iberian Variscan Belt (Fernández-Suárez et al. 1998). These ages have also been found in detrital zircons from Cambrian and Ordovician sedimentary rocks of Iberia (Fernández-Suárez et al. 2000a, 2000b, 2002).

The second age group (ca. 520-530 Ma) is represented in this data set by only two core analyses, which could correspond to Cambrian rifting events, of which there is widespread evidence in Iberia (Sánchez García et al. 2003 and references therein). This Cambrian rifting event is related globally to the initial stages of the breakup of the supercon- 

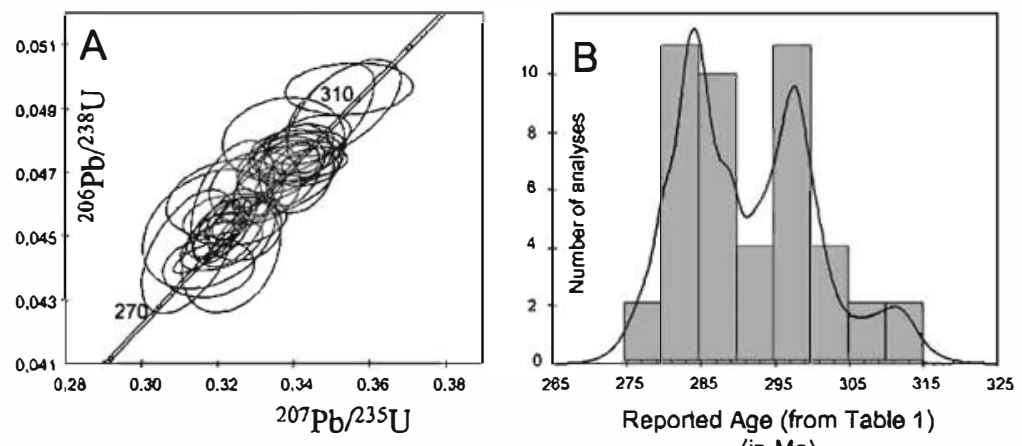

(in $\mathrm{Ma}$ )
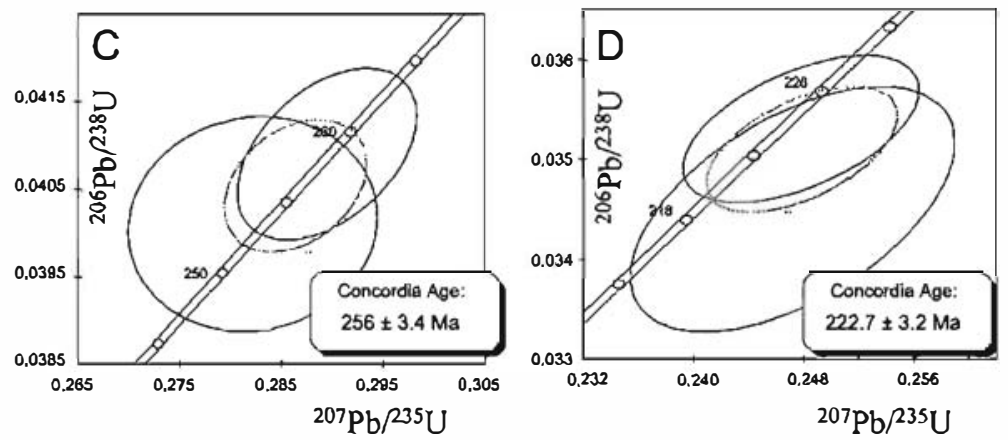

Figure 5. U-Pb concordia plots of showing analyses of Variscan and post-Variscan zircons. $A, B$, Variscan zircons: concordia plot $(A)$ and relative age probability plot $(B)$. Ages and errors used to construct the relative probability plot are those quoted as "reported ages" in table A1. $C, D$, Concordia plots of analyses of post-Variscan zircon overgrowths (see text for details).

tinent Gondwana and the opening of the Rheic Ocean after the end of the Cadomian-AvalonianPan-African orogeny (Keppie et al. 2003). These ages have also been found in detrital zircons from Ordovician and Silurian sandstones and conglomerates of NW Iberia (Martínez-Catalán et al. 2004).

The third age group (ca. 460-490 Ma, found as cores in type B zircons) corresponds to the crystallization ages of pre-Variscan orthogneisses in the SCS (Valverde-Vaquero and Dunning 2000) and other areas of NW Iberia. The tectonic setting of this event is controversial because some authors favor an arc-related environment (ValverdeVaquero and Dunning 2000), whereas others attribute this event to further extension and thinning of the crust following the rifting initiated in the Cambrian (Fernández-Suárez et al. 2000a, 2000b). In either case, this event, manifest in abundant magmatism in upper crustal levels, is also recorded in the lower crust.

The fourth group of ages (277-312 Ma) represents an overwhelming majority (ca. $70 \%$ ) of the zircons analyzed in this study. The predominance of zircons in this age group indicates that the Iberian granulitic lower crust underwent extensive melting and recrystallization over a ca. 30-Ma period starting in late Carboniferous times and ending in the Permian. The 277-312 Ma ages correspond to posttectonic (postcollisional) magmatic pulses in the Iberian Variscan Belt and are matched by U-Pb (zircon and monazite) and Rb-Sr isochron ages of exposed granitoids (Serrano Pinto et al. 1987; Villaseca et al. 1995; Bea et al. 1999; Fernández-Suárez et al. 2000 a). The two peaks apparent in the relative probability plot (fig. $5 \mathrm{~B}$ ) are consistent with the pattern indicated by precise ID-TIMS U-Pb zircon and monazite ages in posttectonic granitoids, which suggest a pulse at ca. 300-295 Ma and a later pulse at ca. 280-288 Ma (Fernández-Suárez et al. 2000a).

This phase of voluminous and widespread granitoid magmatism has been interpreted either as the result of postcollisional lithospheric delamination and concomitant elevation of temperatures in the lower crust (Fernández-Suárez et al. 2000a; Gutiérrez Alonso et al. 2004) or as the result of high crustal radioactive heat production after the crustal thickening produced by the collision (Villaseca et al. 1999). The thermal effect in either case would 
have been to raise lower crustal temperature above $900^{\circ} \mathrm{C}$ (Villaseca et al. 1999), causing widespread melting. The thermal scenario inferred from the study of the surface geology is consistent with the overwhelming presence of zircons with crystallization ages between 312 and $277 \mathrm{Ma}$, which fits the time requirements for the lower crust to have achieved that thermal state after the collision and concomitant crustal thickening (Villaseca et al. 1998 initiated ca. 80-90 m.yr. earlier (MartínezCatalán et al. 1997). Besides the geochronological evidence linking lower crustal melting with granitoid production and subsequent emplacement in the upper crust, the felsic granulite xenoliths match the mineralogical, geochemical, and isotopic requirements to be melting residua after the extraction of melts of composition akin to that of the Variscan granitoids of the SCS (Villaseca et al. 19991.

It is interesting to note that although granitoids older than ca. 312 Ma exist in present-day outcrops of the SCS and other areas of the Iberian Belt lages mostly between ca. 315 and $340 \mathrm{Ma}$ |Serrano Pinto et al. 1987; Villaseca et al. 1995; Bea et al. 1999; Fernández-Suárez et al. 2000a]), these ages have not been found in zircons from the xenolith. Excluding the unlikely possibility that these older zircons have been removed by later events, the only explanation for their absence is that the $>315-\mathrm{Ma}$ magmatism is related to processes occurring in middle-upper crustal sections with little or no reflection in the lower crust. This is consistent with interpretations of syncollisional magmatism that relate its genesis with decompression melting in the middle-upper crust as a response to the onset of the extensional collapse of the orogenic belt ¡Fernández-Suárez et al. 2000a). These >315-Ma syncollisional granitoids are mainly leucogranites with little or no evidence of mantle participation in their genesis, which is consistent with the proposed noninvolvement of lower crustal-upper mantle regions in this event. This inference is important for models of tectonic evolution of collisional mountain belts and shows that, indirectly, the study of $\mathrm{U}-\mathrm{Pb}$ ages in zircons from lower crustal xenoliths can help to clarify important issues in the geological evolution of the upper and middle crust of a certain region. A note of caution must, however, be introduced here because granitoids older than $325 \mathrm{Ma}$ are scarce in the SCS and this study is based on one xenolith sample. We do not, therefore, exclude the possibility that the study of zircon U-Pb ages in more xenoliths of this suite could yield older Carboniferous ages.

The fifth age group is represented by two zircon rims (overgrowths) yielding overlapping ellipses with a concordia age of ca. $256 \mathrm{Ma}$ that is coeval with the crystallization age of the alkaline dikes. Therefore, we suggest that these zircon rims grew in the xenolith during its residence in the alkaline magma and concomitant ascent to the upper crust.

Finally, the sixth age group is represented by two analyses of zircon rims, which yielded overlapping error ellipses with a concordia age of ca. $223 \mathrm{Ma}$. This age postdates the emplacement age of the dike swarm and is consistent with apatite fission track ages between ca. 230 and $214 \mathrm{Ma}$ from the northern sector of the SCS (Bruijne and Andriessen 2000), where the xenolith sample was collected. These zircon rims could have formed in relation to localized hydrothermal or low-temperature processes related to the uplift of the northern sector of the SCS.

In both cases (the ca. 256- and 223-Ma pairs of analysesi, if these young ages were due to lead loss or mixing of isotopic domains, then it would be highly unlikely that the analyses would overlap, given the nature of lead loss and mixing; i.e., it is highly unlikely to find two rims with nearly equal amounts of $\mathrm{Pb}$ loss or to ablate a mixed domain with nearly the same proportions of two or more components. Therefore, we consider that the most likely possibility is that those rims represent late (local) zircon growth, as suggested above. This interpretation is strengthened by the fact that both ages correspond to events whose existence has been independently established. However, given the relatively large uncertainties of individual analyses and the near parallelism of concordia and lead loss chords in this time span, the possibility of these analyses representing lead loss cannot be entirely ruled out.

Some Thoughts on Crustal Recycling. It is clear from the above data that the Ibcrian lower crust underwent a very extensive melting episode at 312 $277 \mathrm{Ma}$. It is also clear from the large volume of granitoids generated in the course of the Variscan orogeny (Villaseca et al. 1999; Ternández-Suárez et al. 2000a) that the Iberian lower crust was very fertile, which is consistent with its previous involvement in an active arc setting (560-590-Ma zircons, Cadomian-Avalonian active margin) and subsequent rifting (520-530 and 460-490 Ma). Both settings are suitable for producing fertile crustal reservoirs (Vielzeuf et al. 1990).

The apparent absence of zircons older than ca. $590 \mathrm{Ma}$ in the Iberian lower crust deserves some consideration here. It is known that the oldest basement exposed within the WEVB is ca. $2 \mathrm{Ga}$ old (Samson and D'Lemos 1998 and references therein), 
and detrital zircon studies in late Neoproterozoic and early Paleozoic rocks from Iberia (FernándezSuárez et al. 1999, 2000b) reveal the presence of a Grenvillian source (ca. 0.9-1.2 Ga) not exposed in the WEVB, in addition to Neoproterozoic sources older than $590 \mathrm{Ma}$ (ca. 600-800 Ma) and Paleoproterozoic (ca. 1.8-2.2 Ga) and minor Archean (2.5$2.7 \mathrm{Ga}$ recycled components. In addition, $\mathrm{Nd}$ model ages $\left(T_{\mathrm{DM}}\right)$ of Cadomian and Variscan granitoids of theria indicate average crustal residence times of ca. 1-1.4 Ga for the crustal sources of those granitoids (Beetsma 1995; Villaseca et al. 1998; Fernández-Suárez et al. 1999). The felsic granulite xenoliths themselves also have $\mathrm{Nd}$ model ages in the range 1.05-1.5 Ga (Villaseca et al. 1999).

In this study, zircons in the age cluster 550-590 Ma were found only as cores within both types of zircons described above and represent ca. $15 \%$ of the data set. Although some of the very small cores observed in scveral zircons (too small for either LAICP-MS or SIMS analyses! could represent remnants of those older (pre-late Neoproterozoic) populations, it can be assumed that virtually all zircons older than ca. 590 Ma have been completely recycled in the lower crust through repeated resetting or melting and crystallization events.

Considering the zircon population of xenolith CSG-1 as estimated from 100 zircons imaged by CL and not only the analyses reported in tables A 1 and 1 (which are biased toward analyzing more cores than their actual proportion?, it can be estimated that zircons older than ca. $312 \mathrm{Ma}$ apresent less than $10 \%$ of total zircon. Therefore, and assuming that no zircon-forming events occurred in the lower crust between ca. $460 \mathrm{Ma}$ and ca. $312 \mathrm{Ma}$, it can be inferred that lower crustal melting under granulite facies conditions caused ca. $90 \%$ of preexisting zircon to be removed by melting and subsequent combination of melt extraction and in situ crystallization or resetting. Likewise, the three earlier consecutive lower crustal events that occurred in a relatively short period of ca. $100 \mathrm{~m}$.yr. at 550$590,520-530$, and 460-490 Ma may have also contributed to the removal of pre-late Neoproterozoic zircons from Iberian lower crustal rocks.

In the time interval irom ca. 590 to $280 \mathrm{Ma}$, the Iberian lower crust could have experienced two episodes of addition of new fertile material (and concomitant rehydration; Vielzeuf et al. 1990) in relation to subduction or underthrusting tectonics. These two episodes would have been related to the late Neoproterozoic Cadomian-Avalonian arc construction and subduction along the northern Gondwanan margin, of which Iberia formed a part (Fernández-Suárez et al. 2002), and to Devono-
Carboniferous underthrusting of the outer edge of Gondwana under the overriding plate in the course of the Variscan collision (Martínez-Catalán et al. 1997). In both these alleged processes of addition of new material to the lower crust, zircons older than $590 \mathrm{Ma}$ i.c., $0.6-0.8,0.9-1.2,1.8-2.2$, or $2.5-$ $2.7 \mathrm{Ga}$ could have been incorporated into the lower crust because they are present in the geological units involved in these underthrusting processes Isee abovel. Therefore, the absence of $>590$-Ma zircons in the xenolith suggests that they were efficiently removed from (1) (hypothetical) pre-late Neoproterozoic zircon-bearing lower crustal rocks and/or (2) upper-middle crustal rocks incorporated into the lower crust in the late Neoproterozoic. This "removal" of >590-Ma zircons would have taken place via repeated episodes of melting/resetting in a period of ca. 300 m.yr. (590-280 Ma).

As for the possibility of addition of significant amounts of fertile material into the lower crust in early Variscan times (ca. 400-380 Ma), if early underthrusting carried significant amounts of upper crustal clements into the lower crust fincluding rocks with $>590$-Ma zircons), it would be hard to reconcile this scenario with the preservation of 590-560-, 530-520-, and 490-460-Ma zircon cores and the absence of $>590$-Ma zircons incorporated into the lower crust after those events. We therefore favor the idea that the latest recorded episode of significant addition of fertile matcrial into the therian lower crust was related to the CadomianAvalonian-Pan-African Neoproterozoic Andeantype orogeny along the northern Gondwanan margin.

The question of the possible existence of "portions" of pre-late Neoproterozoic bascment forming part of the Iberian lower crust cannot be answered with the data obtained in this study. But our contention is that it is rather unlikely that the therian lower crust has retained any "solid remnants" carrying U-Pb isotopic information before ca. $600 \mathrm{Ma}$, in contrast to the "memory" of the neodymium isorope system that suggests crustal growth older than $1 \mathrm{Ga}$ (see abovel.

\section{Concluding Remarks}

U-Pb zircon ages in a single xenolith extracted from the Iberian lower crust in early Mesozoic times record lower crustal processes spanning ca. $400 \mathrm{~m}$.yr., matching events recorded on the surface geology of theria and retated to major episodes including (1) the late Neoproterozoic Cadomian-Avalonian orogeny on the northern margin of Gondwana, (2) rifting 
of the northern Gondwanan margin and opening of the Rheic Ocean, 13 ! collisional Variscan orogenesis, and (4) early stages of rifting and mantle melting leading to the opening of the Atlantic Ocean.

As a general conclusion, it can be stated that U$\mathrm{Pb}$ zircon geochronology of lower crustal xenoliths can offer constraints on the geological evolution of a terrane or lithospheric fragment over extended periods of time that in some cases (such as that reported here) span several major orogenic events.

It is also shown that although most processes in the upper-middle crust are imaged in the lower crust, some processes may occur exclusively in either of these crustal domains and have little or no reflection in the other.

The study reported here suggests that in lithospheric purtions involved in active tectonic scenarios such as (1) magmatic arc construction and subduction, (2) rifting, and |3| collisional orogenesis, lower crustal recycling occurs at a taster pace, and at any given time, evidence jas deduced from zircon U-Pb ages) for processes that occurred in previous events is likely to have been partially or completely obliterated.

\section{A C KNOWLEDGM ENTS}

J. Ternández-Suárez acknowledges a European Union grant under the Training and Mobility of Researchers program (project HIGH LAT) that funded ion microprobe analyses at NORDSIM (Stockholm). J. Fernández-Suárez and T. E. Jeffries are grateful to the Electron Microscopy and Mineral Analysis Division at the Natural History Museum (London) for logistic assistance and to K. Billstrom for his warm welcome at the Natural History Museum (Stockholm). The NORDSIM facility is $\mathrm{f}$ nanced and operated under an agreement between the joint Nordic research councils (NOS-N), the Geological Survey of Finland, and the Swedish Museum of Natural History. This is NORDSIM contribution 147.

\section{REFERE N C ES C I T E D}

Andersen, T. 2002. Correction of common lead in U-Pb analyses that do not report ${ }^{204} \mathrm{~Pb}$. Chem. Geol. 192: $59-79$

Bea, F.; Montero, P.; and Molina, J. F. 1999. Mafic precursors, peraluminous granitoids, and late lamprophyres in the Avila batholith: a model for the generation of batholiths in Iberia. J. Geol. 107:399-419.

Beetsma, J. J. 1995. The late Proterozoic/Paleozoic and Hercynian crustal evolution of the Iberian Massii, N Portugal, as traced by geochemistry and $\mathrm{Sr}-\mathrm{Nd}-\mathrm{Pb}$ isotope systematics of pre-Hercynian terrigenous sediments and Hercynian granitoids. PhD thesis, Vrige Universiteit, Amsterdam, $223 \mathrm{p}$.

Bruıne, C. H., and Andriessen, P. A. M. 2000. Interplay of intraplate tectonics and surface processes in the Sierra de Guadarrama (central Spain) assessed by apatite fission track analyses. Phys. Chem. Earth 25: 555-563.

Cebriä, J. M.; López-Ruíz, J.; Doblas, M.; Martins, L. T.; and Munha, J. 2003. Geochemistry of the Early Jurassic Messejana-Plasencia dyke (Portugal-Spain); implications on the origin of the Central Atlantic Magmatic Province. J. Petrol. 44:547-568.

Chen, Y. D.; O'Reilly, S. Y.; Kinny, P. D.; and Griffin, W. L. 1994. Dating lower crust and upper mantle events: an ion microprobe study of xenoliths from kimberlitic pipes, South Australia. Lithos 32:77-94.

Davis, W. J.; Canil, D.; Mackenzie, J. M.; and Carbno, G. B. 2003. Petrology and U-Pb geochronology of lower crustal xenoliths and the development of a craton, Slave Province, Canada. Lithos 71:541-573.
Downes, H. 1993. The nature of the lower continental crust of Europe: petrological and geochemical evidence from xenoliths. Phys. Earth Planet. Inter. 79: 195-218.

Downes, H.; Peltonen, P.; Mänuäri, I.; and Sharkov, E. V. 2002. Proterozoic zircon ages from lower crustal granulite xenoliths, Kola Peninsula, Russia: evidence for crustal growth and reworking. J. Geol. Soc. Lond. 159: 485-488.

Fơrnándcz-Suárcz; J.; Dunning, G. R.; Jenner, G. A.; and Gutiérrez Alonso, G. 2000a. Variscan collisional magmatism and deformation in NW Iberia: constraints from U-Pb geochronology of granitoids. J. Geol. Soc. Lond. 157:565-576.

Fernandez-Suarez, J.; Gutiérrez Alonso, $G_{\text {.; }}$ and Jeffries, T. E. 2002. The importance of along-margin terrane transport in northern Gondwana: insights from detrital zircon parentage in Neoproterozoic rocks from Iberia and Brittany. Earth Planet. Sci. Lett. 204:75-88.

Fornándcz-Suárcz: J.; Gutiérrez Alonso, G.; Jenner, G. A.; and Jackson, S. E. 1998. Geochronology and geochemistry of the Pola de Allande granitoids (northern Spain): their bearing on the Cadomian/Avalonian evolution of NW Iberia. Can. J. Earth Sci. 35:1439-1453.

Fernandez-Suarez, J.; Gutiérrez Alonso, G.; Jenner, G. A.; and Tubretı, M. N. 1999. Crustal sources in lower Palaeozoic rocks from NW Iberia: insights from laser ablation U-Pb ages of detrital zircons. J. Geol. Soc. Lond. 156:1065-1068.

2000b. New ideas on the Proterozoic-early Pa- 
laeozoic evolution of NW Iberia: insights from U-Pb detrital zircon ages. Precambrian Res. 102:185-206.

Gardien, V., and Paquette, J. L. 2004. Ion microprobe and ID-TIMS U-Pb dating of zircon grains from Leg 173 amphibolite: evidence for Permian magmansm in the west Iberian margin. Terra Nova 16:226-231.

Gutiérrez Alonso, G.; Fernandez-Suarez, J.; and Weil, A. B. 2004. Orocline triggered lithospheric delamination. Geol. Soc. Am. Spec. Pap. 383:121-130.

Höltä, P.; Huhnıa, H.; Mänttäri, I.; Peltonen, P.; and Juhanoja, J. 2000. Petrology and geochemistry of mafic granulite xenoliths from the Lahtojoki kimberlite pipe, eastern Finland. Lithos 51:109-133.

Jackson, S. E.; Pearson, N. J.; Griffin, W. L.; and Belousova, E. A. 2004. The application of laser ablation inductively coupled plasma mass spectrometry to in-situ U-Pb zircon geochronology. Chem. Geol. 211:47-69.

Jeffries, T. E.; Fernández-Suárez, $\mathrm{I}$; Cortu, $\mathrm{P}$; and Gutiérrez Alonso, G. 2003. Advances in U-Pb geochronology using a frequency quintupled $\mathrm{Nd}$ :YAG based laser ablation system $(\lambda=213 \mathrm{~nm})$ and quadrupole based ICP-MS. J. Anal. Atom. Spectron. 18: 847-855.

Keppie, J. D.; Nance, R. D.; Murphy, J. B.; and Dostal, J. 2003. Tethyan, Mediterranean, and Pacific analogues for the Neoproterozoic-Paleozoic birth and development of peri-Gondwanan terranes and their transfer to Laurentia and Laurussia. Tectonophysics 365: 195-219.

Ludwig, K. R. 1998. On the treatment of concordant uranium-lead ages. Geochim. Cosmochim. Acta 62: 665-676.

2001. Isoplot/Ex [ver. 2.49). Berkeley Geochronol. Cent. Spec. Publ. 1A, 55 p.

Martínez-Catalan, J. R.; Arenas, R.; Diaz García, F; and Abati, J. 1997. Variscan accretionary complex of NW Iberia: terrane correlation and succession of tectonothermal events. Geology 25:1103-1106.

Martínez-Catalán, J. R.; Fernández-Suảrez, J.; Jenner, G. A.; Belousova, E. A.; and Díez Montes, A. 2004. Provenance constraints from detrital zircon U-Pb ages in the northwestern Iberian Massif: implications for Paleozoic plate configuration and Variscan evolution. J. Geol. Soc. Lond. 161:463-476.

Moser, D. E., and Heaman, L. M. 1997. Proterozoic zircon growth in Archean lower crustal xenoliths, southern Superior craton: a consequence of Matachewan ocean opening. Contrib. Mineral. Petrol. 128:164-175.

Murphy, J. B.; Fernaindez-Suarez, J.; and Jeffries, T. E. 2004. Lithogeochemical, $\mathrm{Sm}-\mathrm{Nd}$ and $\mathrm{U}-\mathrm{Pb}$ isotopic data from the Silurian-Early Devonian Arisaig Group clastic rocks, Avalon terrane, Nova Scotia: a record of terrane accretion in the Appalachian-Caledonide orogen. Geol. Soc. Am. Bull. 116:1183-1201.

Pin, C., and Vielzeuf, D. 1983. Granulites and related rocks in median Europe: a dualistic interpretation. Tectonophysics 93:47-74.

Rudnick, R. L. 1995. Making continental crust. Nature 378:571-578.

Rudnick, R. L., and Cameron, K. L. 1991. Age diversity of the deep crust in northern Mexico. Geology 19: 1197-1200.

Rudnick, R. L., and Williams, I. S. 1987. Dating the lower crust by ion microprobe. Earth Planet. Sci. Lett. 85: $145-161$.

Samson, S. D., and D'Lemos, R. S. 1998. U-Pb geochronology and $\mathrm{Sm}-\mathrm{Nd}$ isotopic composition of Proterozoic gneisses, Channel Islands, UK. J. Geol. Soc. Lond. 155:609-618.

Sánchez Crarcía, T.; Bellido, F.; and Quesada, C. 2003. Geodynamic setting and geochemical signatures of Cambrian-Ordovician rift-related igneous rocks 10 ssa Morena zone, SW Iberia). Tectonophysics 365:233255.

Schmitz, M. D), and Bowring, S. A. 2000. The significance of U-Pb zircon dates in lower crustal xenoliths from the southwestern margin of the Kaapvaal craton, southern Africa. Chem. Geol. 172:59-76.

Sebai, A.; Feraud, G.; Bertrand, H.; and Hanes, J. 1991. ${ }^{\circ} \mathrm{Ar}$ Ar dating and geochemistry of tholeiitic magmatism related to the early opening of the Central Atlantic rift. Earth Planet. Sci. Lett. 104:455-472.

Serrano Pinto, M.; Casquet, C.; Ibarrola, E. Corretge, L. $G_{i}$ and Portugal Ferreira, M. 1987. Síntese geocronológica dos granitoides do Macizo Hespérico. In Bear, F., ed. Geología de los granitokdes y rocas asociadas del Macizo Hespérico. Madrid, Rueda, p. 69-86.

Stacey, J. S., and Kramers, J. D. 1975. Approximation of terrestrial lead isotope evolution by a two-stage model. Earth Planet. Sci. Lett. 26:207-221.

Valverde-Vaquero, P., and Dunning, G. R. 2000. New U$\mathrm{Pb}$ ages for Early Ordovician magmatism in central Spain. J. Geol. Soc. Lond. 157:15-26.

Vielzeuf, D.; Clemens, J. D.; Pin, C.; and Moinet, C. 1990. Cranites, granulites and crustal differentiation. In Vielzeuf, D., and Vidal, P., eds. Granulites and crustal evolution. Dordrecht, Kluwer, p. 59-85.

Villaseca, C.; Barbero, L.; and Rogers, G. 1998. Crustal origin of Hercynian peralummous granitic batholiths of central Spain: petrological, geochemical and isotopic (Sr-Nd) arguments. Lithos 43:55-79.

Villaseca, C.; Downes, H.; Pin, C.; and Barbero, L. 1999. Nature and composition of the lower continental crust in central Spain and the granulite-granite linkage: inferences from granulitic xenoliths. J. Petrol. 40: $1465-1496$.

Villaseca, C.; Eugercios, L.; Snelling, N.; Huertas, M. J.; and Castellon, T. 1995. Nuevos datos geocronológicos (Rb-Sr, K-Ar) de granitoides hercínicos de la Sierra de Guadarrama. Rev. Soc. Geol. Esp. 8:137-148.

Villaseca, C.; Huertas, M. J.; and Nuez, J. 1991. Magmatismo post-orogénico y anorogénico en el Sistema Central Español. Grogaccta 11:34-38.

Villaseca, C; Orejana, D.; Pin, C.; López-Carcia, I. A.; and Andonaegui, P. 2004. Le magmatisme basique hercynien et post-hercynien du Système Central Espagnol: essai de caractérisation des sources mantelliques. C. R. Geosci. 336:877-888.

Watson, E. B. 1996. Dissolution, growth and survival of zircons during crustal fusion: kinetic principles, geo- 
logical models and implications for isotopic inheritance. Trans. R. Soc. Edinb. Earth Sci. 87:43-56.

Whitehouse, M. J.; Kamber, B.; and Moorbath, S. 1999. Age and significance of U-Th-Pb zircon data from early Archaean rocks of west Greenland: a reassessment based on combined ion microprobe and imaging studies. Chem. Geol. 160:201-224.

Wiedenbeck, M.; Allé, P.; Corfu, F.; Griffin, W. F.; Meier,
M.; Orbeli, F.; von Quadt, A.; Roddick, J. C.; and Spiegel, W. 1995. Three natural zircon standards for U-Th$\mathrm{Pb}, \mathrm{Lu}-\mathrm{Hf}$, trace element and REE analyses. Geostand. Newsl. 19:1-23.

Zheng, J.; Griffin, W. L.; O'Reilly, S. Y.; Lu, F.; Wang, C.; and Zhang, M. 2004. 3.6 Ga lower crust in central China: new evidence on the assembly of the north China Craton. Geology 32:229-232. 